\title{
EXPRESSART: A Project-Based Language Learning Experience
}

\author{
Javier Barba \\ Escola Nostra Llar i Universitat Autònoma de Barcelona, Spain
}

Article received 16 September 2016, accepted 5 October 2016, final version 17 December 2016

DOI: http://dx.doi.org/10.5565/rev/jtl3.689

\begin{abstract}
This article aims to compare two different methodologies (implemented by a single teacher in an practitioner research approach) used in a 4th year English classroom in a public primary school in Catalonia. To do this comparison, different outcomes from students were collected and analysed to answer different questions related to Project Based Language Learning approach (PBLL) and what the author calls Course-Book Driven approach (CBD). The article examines, through the analysis of the students' productions and of the focus group, the evidence of gains in written language and the motivation of the students depending on the approach used. The article concludes with several implications for research and practice.
\end{abstract}

Key words: project, language learning, multimodal communicative output, motivation, collaboration

\section{Resumen}

Este artículo tiene como objetivo comparar dos metodologías diferentes (practicadas por un docente en una investigación-acción) llevadas a cabo en la clase de cuarto de primaria durante las sesiones de inglés, en una escuela pública de primaria en Cataluña. Para realizar esta comparación, diferentes producciones de los alumnos fueron recogidas y analizadas con el objetivo de responder a diferentes preguntas relacionadas con el aprendizaje de la lengua basado en proyectos (PBLL) y con el que el autor define como metodología de uso del libro (CBD). El artículo examina, a través del análisis de las producciones de los alumnos y de un focus group, la evidencia de ganancia de lenguaje escrito y de motivación por parte de los alumnos dependiendo de la metodología utilizada. El artículo concluye con algunas implicaciones relacionadas tanto con la investigación como con la práctica.

Palabras clave: proyecto, aprendizaje de lengua, productos comunicativos multimodales, motivación, colaboración

\section{Resum}

Aquest article té com a objectiu comparar dues metodologies diferents (practicades per un docent en una investigació-acció) portades a terme a una classe de quart de primària durant les sessions d'anglès, a una escola pública de primària de Catalunya. Per realitzar aquesta comparació, diferents produccions dels alumnes van ser recollides $\mathrm{i}$ analitzades amb l'objectiu de respondre a diferents preguntes relacionades amb l'aprenentatge de la llengua basat en projectes (PBLL) i amb el que l'autor defineix com a metodologia d'ús del llibre (CBD). L'article examina, a través de l'anàlisi de les produccions dels alumnes i d'un focus group, l'evidència de guanys en llengua escrita $i$ en motivació per part dels alumnes depenent de la metodologia emprada. L'article 
conclou amb algunes implicacions relacionades tant amb la investigació com amb la pràctica.

Paraules clau: projecte, aprenentatge de llengua, productes comunicatius multimodals, motivació, col·laboració

\section{Introduction}

In this article, two different professional approaches, as applied personally by this researcher, to language teaching are compared (approach 1 is what the researcher has called 'CourseBook Driven' (or CBD approach) and approach 2 is Project Based Language Learning (or PBLL), see (Beckett \& Miller, 2006). These professional approaches are based in a practitioner research (Kara, 2012; Allwright, 2003) (herein PR) that looks at the researcher's own teaching practice from a socio-constructivist perspective (the notion that knowledge is a shared creation that takes place through interaction; cf. Lantolf, 2000, 2004; Lantolf \& Poehner, 2008; Vygotsky, 1978).

$\mathrm{CBD}$ is what this researcher defines as using textbooks to teach English as a foreign language in a more, for lack of a better term, 'conventional' way. That implies following quite strictly the organization of lessons according to a "Pupil's book" and an "Activity book" and the activities proposed. It is recognized that even though the authors and publishers of such books have endeavoured to ensure that the reading, writing, speaking and listening activities are related to the students' interests (school subjects, animals, computers, etc.), it still must be acknowledged that these topics and subsequent proposed activities are not necessarily meaningful in the sense that they are not chosen by the students. Furthermore, coursebooks, by nature, must be generic enough to sell worldwide.

PBLL is understood in this context as assignments, tasks and activities that segue into a main output and which help the students work on different competences simultaneously (e.g. designing, planning and setting up an artwork production). These activities revolve around different learning aims (e.g. understanding architectural and engineering techniques as in the previous example) while integrating other skills (e.g. learning to negotiate, make compromises and collaborate).

With these two approaches in mind, this study aims to study which methods can be be optimized to ensure language learning in foreign language classrooms, this study takes an introspective look at teaching practices, with an aim to innovate and renew teaching and learning processes in the language classroom, based on sociocultural premises that bring the importance of interaction to the fore. 
It is necessary to reconceptualize language, context, and learning in profound ways if we wish to reap the benefits of the visions presented at the beginning of the beginning of the 20th century by Bakhtin, Dewey, Vygotsky, and others, whose message once again become prominent. (Van Lier, 2000, p. 247)

\section{Theoretical framework}

This article is based in a practitioner research (herein PR) that looks at this (author) teacherresearcher's teaching practice from a socio-constructivist perspective, placing particular emphasis on the the notion that knowledge is a shared creation that takes place through interaction (Chapman, Ramondt \& Smiley, 2005). That premise means that people learn while participating and interacting in social activities with other people (Vygotsky, 1978), in other words, learning takes place through the social interaction with others.

Wenger (2015) defends that all learning happens through the interaction of the members of a Community of Practice $(\mathrm{CoP})$, in an environment where the novice members interact with the experts to acquire tools (and skills) to improve their abilities. In this sense, a school can be considered a Community of Practice, and the English classroom or the English lessons are another community of practice inside the school. In this CoP, part of the normative 'rules' is the fact that there is another language that reshapes the rules of language usage. Learning to recognize and use the CoP language is part of becoming a member of the community - members are 'validated' by other members in the main community through their use of that language (Masats, Nussbaum \& Unamuno, 2007). So, for example, the communication with the teacher and the classmates in the EFL classroom changes, normally, into English and the linguistic strategies will also be different. The students are aware of the changes and they make decisions on how to behave and interact with other members of the CoP according to the situation. As Negueruela-Azarola, García, and Buescher put it:

From an SCT learning and development perspective, classroom behavior that is dynamic and directed to others (interactive) integrates a rich dance of talking, gazing, listening, gesturing, reading, and writing. The assumed main goal for all these different types of interactions is to maximize learning opportunities. $(2015$, p. 235)

The socioconstructivist premise not only informs the teaching that is examined in this study (and the subsequent interventions that form part of the research data), socioconstructivism also provides the theoretical underpinnings of the approach to the qualitative analysis, which is divided into three phases: 1) A secondary research in order to elaborate the initial criteria for the content analysis (Strauss \& Corbin, 1990) that is carried out on the written data collected from the students; 2) Data analysis of the content of written output from four 
students. Grounded theory has been used to analyze student's productions as part of this content analysis of the written texts. In grounded theory, categories are linked and organized according to identified relationships or themes, in a process called axial coding (Glaser, 1978). Finally the third phase 3 ) is a focus group analysis from the same four students that take part in phase number two. It is important to note that a focus group is not a casual talk but instead it is a planned conversation in order to obtain information from an area of interest in a permissive and relaxed atmosphere (Krueger, 1991).

The principle reason for this comparative analysis of the two approaches is due to the fact that nowadays in Catalunya, education tries to follow the notion of projects as a way of teaching-learning methodology at schools. This implies that the roles of the teachers and the students must change as they adjust to this more interactive approach to teaching and learning. In a project approach, teachers are guides; they are no longer the sole 'holders' of the content knowledge the students may engage in. Students, on the other hand, have more liberty to express their needs and their interests (e.g. student-centred focus). Ideally, they are responsible for their own learning process and the project engages them to develop their skills through carefully designed, integrated tasks (Dooly, 2010; 2016). In short, project work can be defined as "long-term, problem-focused, and meaningful activities that bring together ideas and principles from different subject areas or disciplines" (Goodrich, Hatch, Wiatrowski, \& Unger, 1995, p. 8).

Corollary to this is the idea that motivation is a very important factor to take into account in this particular type of teaching-learning process. If students are more motivated, perhaps they will be willing to learn more, make bigger efforts, give their opinions, innovate with the language, etc. It has been argued convincingly elsewhere that working through projects can increase students' motivation towards the learning process (Stoller, 2002), including the learning of a foreign language. Indeed, a noticeable swing towards its use has been detected.

In fact, in the past years in English lessons, a change has begun and teachers all over the country are trying to use the PBLL methodology to teach a part of that language in their classrooms. Teachers are not the centre of the learning process anymore. This approach plays a very important role in language teaching because it not only allows for a practical and meaningful approach to teaching and assessing language learning; it also promotes effective learning strategies and critical thinking skills (Dooly, 2013). 
It has also been pointed out that in the Spanish education system there has still been little research focused on this aspect (Sierra, 2011). This study aims to take a small step in the direction.

\section{Research context}

The compilation of the data for the research takes place in a public primary school in the centre of Sabadell (municipal area of Barcelona). The families that bring their children to the school are, in general terms, economically middle class with a high socio-cultural level. On the whole, these families are of the opinion that school is important for their children and they demonstrate support to the school, the teachers and their initiatives. The school is located in a Catalan speaking community and the percentage of immigrants is around $2 \%$. The teacherresearcher has been working at the school for the last four academic years.

In the school there are 18 groups from P-3 through the 6th form with a total number of 450 children. Students are introduced to English as a Foreign Language (EFL) as early as P4 (4 years old) and English lessons continue through all of the grades. In the last two primary grades, apart from the EFL lessons, science is taught in English too.

We are looking at a practitioner-research, thus the study takes place in the researcher's (teacher's) classroom. This means that while the researcher is collecting the data he is also involved with the analyzed group as their teacher (for different discussions of research wherein the teachers takes the role of researchers in their own classroom, see Adelman, 1993; Bartlett \& Burton, 2006; Ferrance, 2000; Pine, 2009; Sagor, 2000; Stringer, 2007).

In the group of the study, there are 26 students: 16 girls and 10 boys. Of the entire class of 26 , four students (two boys and two girls) were chosen to serve as the focal point for the data compilation (to analyze their writings and to take part in a focus group). They have been chosen for several reasons: a) equitable representation of gender; b) they have always been together at the same school and in the same group since beginning their schooling; c) they are generally quite talkative so it was felt they would be more participative during the focus group; d) they took part in all of the tasks that were analysed.

The students in the class are 10 years old and they are, in general, very motivated for the lessons at school (across different subjects). They enjoy EFL for different reasons such as communicating while travelling abroad (they find it useful because when they travel they can talk with other children) and because we have international projects with schools from different European countries (thus they see its immediate relevancy). They also think that 
English is an important language if they want to use (and understand) Internet or if they want to know the meaning of their favourite pop songs.

\section{Activity/Activities implemented}

Two data sets are used in this research.

Data set 1: Written texts derived from classroom procedures (CBD \& PBLL)

The output is:

\begin{tabular}{|l|l|}
\hline \multicolumn{2}{|c|}{ Comparing - Analysing outputs } \\
\hline \multicolumn{1}{|c|}{$C B D$ approach } & \multicolumn{1}{|c|}{$P B L L$ approach } \\
\hline $\begin{array}{l}\text { Two different written texts proposed } \\
\text { by the book }\end{array}$ & $\begin{array}{l}\text { Written texts within the project: } \\
\text { Introduction proposed by the students } \\
\text { themselves }\end{array}$ \\
$\begin{array}{l}\text { Content: } \\
\text { A day at school } \\
\text { My favourite book }\end{array}$ & $\begin{array}{l}\text { Content: } \\
\text { Myself About my town and } \\
\text { Personal object (created in arts \& crafts) }\end{array}$ \\
\hline
\end{tabular}

Table 1. Comparison of output from both approaches

Within the CBD approach, there are two different written texts proposed by the course book (Tiger Tracks, from Macmillan Publishers). 'A day at school' was written in November 2013 and 'My favourite book' was written in February 2014.

The classroom procedure with each writing process and product is the following: One session with the full group (1h) is devoted to talking about the topic of the writing task, taking notes and starting the draft. One session with the half group (45 minutes +45 minutes) is devoted to writing the draft and asking questions to the teacher (the teacher gives feed-back to the students). If a student has not finished the draft, he or she can finish it at home. The teacher takes all the drafts home to correct them and in a session with the half group (45 minutes +45 minutes) gives them back with individual feedback. Students start the final product (the final text should be without mistakes and be accompanied with drawings). If they do not finish the final output at school, they can finish it at home.

Within the PBLL approach, there is an activity in which students write about themselves, about their town and about a personal object (activity carried out in April 2014). This writing was contextualized within an international project in the school (VoiceS project) - the students were writing to their partners in an Austrian school to introduce themselves and describe their town to students and teachers from abroad.

The classroom procedure for the introduction texts is the following: One session with the full group (1h) is devoted to talking about the topics of the writing, taking notes and 
starting the drafts (they could choose to start by writing about themselves or about their town). Two sessions with the half group ( 45 minutes +45 minutes) are devoted to writing the drafts and asking questions to the teacher (the teacher gives feed-back to the students). If a student has not finished the drafts, he or she can finish them at home. The teacher takes all the drafts home to correct them and in a session with the half group (45 minutes +45 minutes) gives back the drafts with individual feedback.

The students also had to write a text about a personal object that they had created previously in an arts and crafts class. The procedure for this text was one session with the full group ( $1 \mathrm{~h}$ and 30 minutes) devoted to creating the object with the art teacher and deciding why they have chosen that object and not another. This was a student initiative as they wanted to create a personal object to add to the poster in order to individually personalize their exchange with the Austrian school. Since the art teacher also wanted to contribute to the project, this was an ideal way to make the language lesson more interdisciplinary. The final step was for the sudents to create the final product (poster, see figure 1), pulling together all the components of the project (texts, drawings, pictures, cardboard, etc.) in a session with the full group (1h).

\section{Data set 2: data from the focus group}

The technique for collecting the data in the focus group was recording audio (only). It was not video recorded because the investigator did not want to make the students more timid. Moreover, because the audio recorder is very similar to a smartphone, it was more familiar to them. The discussion was held in a small classroom in a relaxed atmosphere. The researcher wanted to be with the four students alone, without other people around because he wanted them to feel comfortable to talk therefore arrangements had been made for the rest of the pupils were in a Catalan lesson with another teacher.

Before starting the recording, it was explained to them what they were going to do and that their parents had agreed with the recording. It was also explained to them that the researcher had been looking at their written texts and that he would like to talk about them. Finally, they were told that it was not an evaluative session - this would not affect their final marks in any way nor any problems with their writing would be pointed out. They were told that the session would be recorded with a digital recorder and that it would help the teacher to complete his research dissertation for a Master's degree (this was explained in terms they could comprehend). 
The purpose with the focus group was getting information from the students concerning their motivation when working through different methodologies. Some questions were asked such as "Is it relevant for you to write to other students from a different country?" "How do you feel about collaborative learning?" "In which kind of writing methodology do you feel safer?" There were also questions related to the more frequent features that emerged from the content analysis of their written output such as "What differences do you see in your writing (showing them examples)?" "I think this is more complex because your sentences are compound (you use and, or) or complex - you use because. What do you think? Why do you think you did this?" After asking the questions, the researcher was quiet in order to give them time to elaborate on their comments because their opinions were very useful for the research. How this data were analysed is explained in more detail in the analysis section below.

\section{Objectives and research questions}

As explained in the introduction, two different teaching approaches to language education are compared. After comparing them, some questions were answered, based on the results of the three-phase analysis described previously.

The first question is "Do PBLL and CBD approaches result in different language learning results?" And the second question is "Can PBLL be applied to writing in contexts which are predominantly oral-production focused?" This question needed to be refined, so two sub-questions were added. The first corollary question is "Is there evidence of gains in (written) language use in PBLL-derived output in comparison to the other approach?" This is answered with the data analysis. And the second one is "Are students more motivated when producing output in PBLL situation than in the teacher-centred approach (CBD)?" This is answered with the focus group.

\section{Analysis}

\section{Data set 1 analysis}

Grounded theory has been used to analyze the students' productions as part of the content analysis of the written texts. In grounded theory, categories are linked and organized according to identified relationships or themes, in a process called axial coding (Glaser, 1978). In order to carry out the axial coding, the data information was first transferred to an Excel chart (see figure 1, below). 


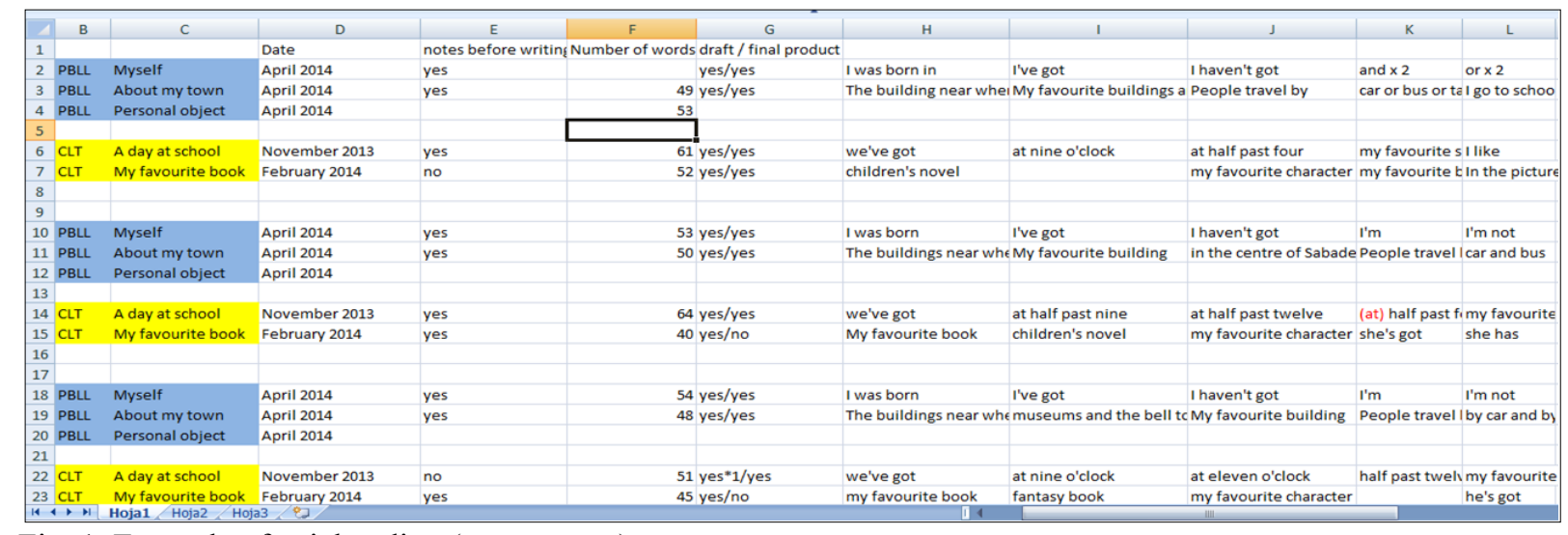

Fig. 1. Example of axial coding (text content)

However, despite the fact that linguistic aspects were chosen for categories (befitting the role of 'teacher evaluation'), it is important to highlight that these categories were not decided $a$ priori. The categories emerged during the data analysis.

'Teacher's perspective' based in output (linguistic aspects): As stated previously, different outputs coming from the students' work are compared: on the one hand, two CBD output are included in the dataset ('A day at school' and 'My favourite book') and on the other, the PBLL output, which is divided into three topics ('Myself', 'About my town' and 'Personal object'). Figures 2, 3 and 4 are examples of the data collected.

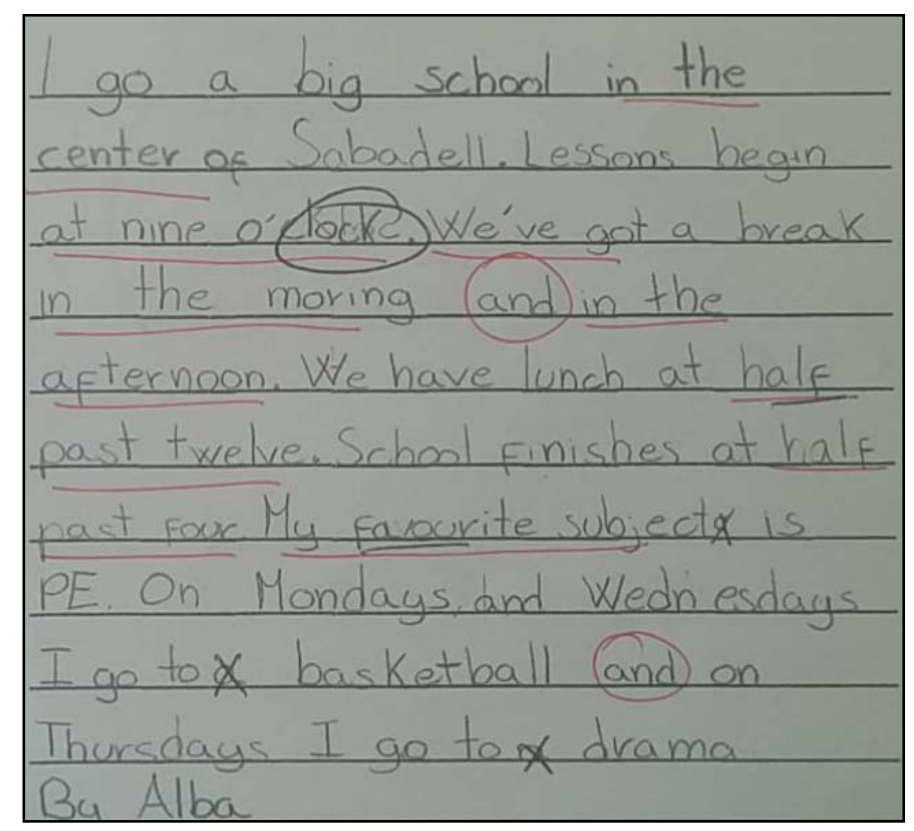

Fig. 2. CBD draft: A day at school 


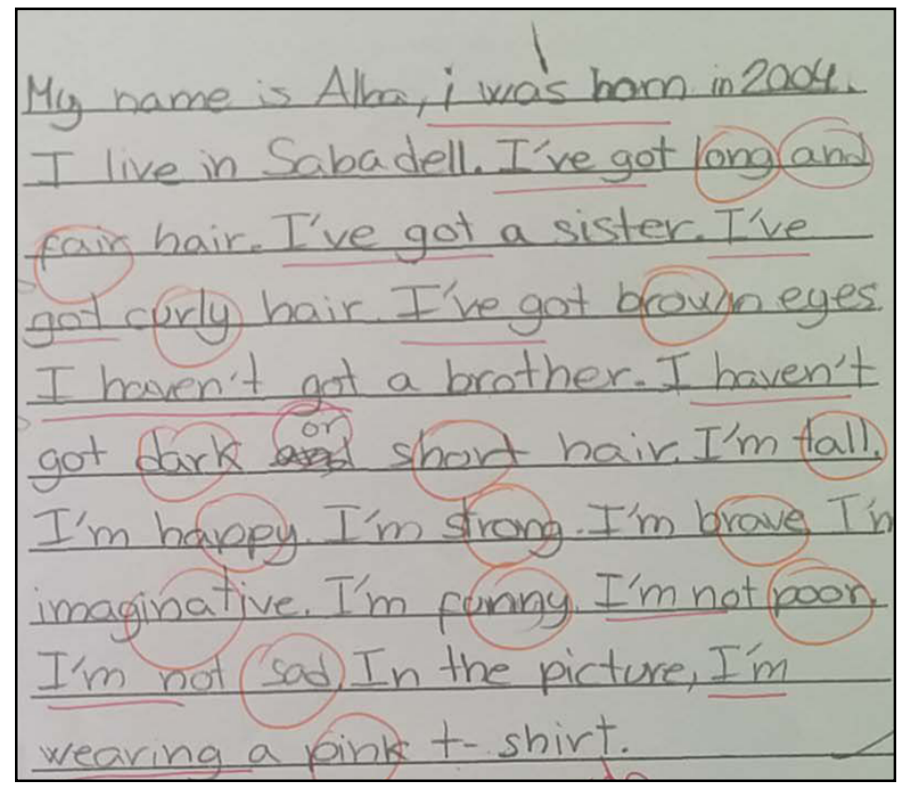

Fig. 3. PBLL draft: Myself

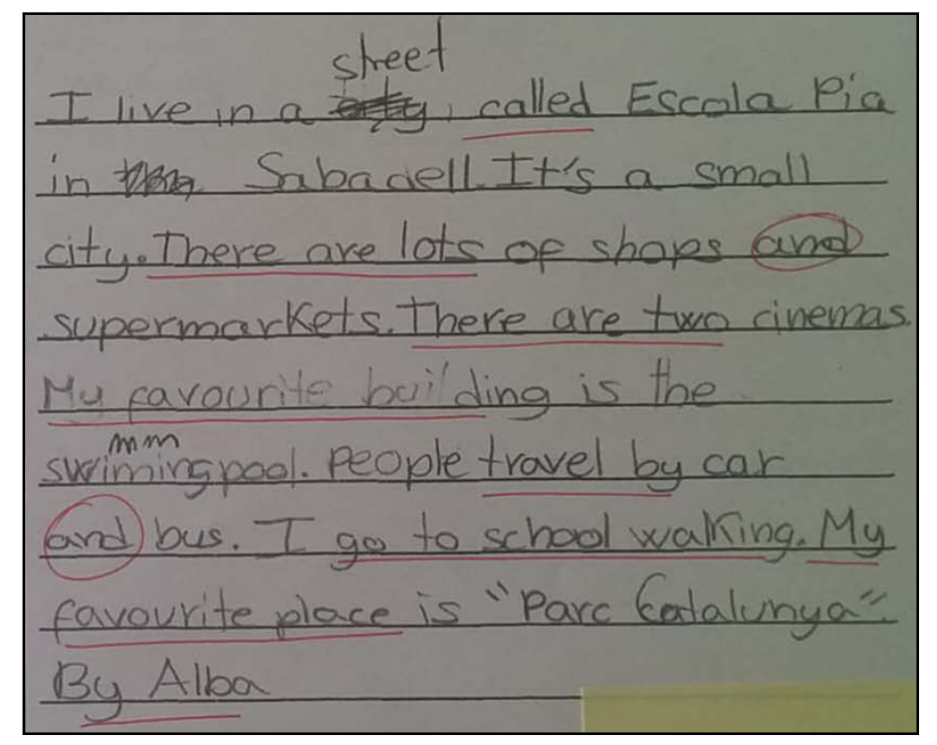

Fig. 4. PBLL draft: About my town

An important part of the writing process is to take notes. This was a feature of the teaching process about how to write in English which was taught explicitly in the class. Thus, from the beginning, students were initiated to the idea that when they write in English it is very useful to write down initial ideas (words, adjectives, connectors, etc.) before trying to craft complete sentences. While in all the PBLL writings students took previous notes (such as words in English, sentences or expressions) before starting to write this did not happen with the CBD writings, two of the four students did not take notes beforehand. Of these two, one of them had to rewrite the entire first draft because the first version made no sense, reinforcing the notion that taking notes is very important before writing because it provides them with a 
guide. This aspect of their writing process was included in the data analysis as a possible indicator of engagement in the writing task.

Another indicator of the students' engagement in the writing task is a quantitative approach of counting the number of words written by the students. In this aspect, there was a big difference between the writings produced within the two approaches. As indicated in the description of the activities, the students decided to write about different things to introduce themselves to students from their partner country and between the writing tasks the amount of words is significantly different. In the CBD output they wrote an average of 69,3 words while in the PBLL they wrote an average of 116,3 words, equal to a $59 \%$ increase in word production.

The notion that students, in general, like to express their opinions when they talk or write was taken into consideration in the analysis. In the CBD writings called "A day at school" and "My favourite book" students expressed what they prefered ten times, using expressions such as "My favourite..." or "I like". In the PBLL writings, they talked about their opinions eight times, using expressions such as "My favourite", "I like" and "I love" but they also explained why (four times) using the connector "because". The use of "because" does not appear in any of the CBD writings. This indicates an attempt at greater complexity in the PBLL texts.

Also, in the PBLL approach writing production, there are several examples of compound and complex sentences. For example, the passive voice can be found in the writing of four students (I was born, a street called). All the students also express their opinions using the expression 'My favourite'. Connections 'and/or' are also used by all the students to link ideas or sentences. In both types of productions contractions such as "I've, We've, I'm, He's" appear.

In texts from both PBLL and CBD two cases of using descriptions can be found. One description is about their favourite character in the CBD productions (about their favorite book). In these texts, the students use an average of 5,75 adjectives per description. The other description is about themselves in the PBLL productions, and in these writings they use an average of 11,75 adjectives. It should be noted that these linguistic features had been discussed in class in both approaches.

'Teacher's perspective' based in output (final products): Even if the process is the most important part of a school task, the final product is the demonstrable (audience-oriented) 
production. Students will usually try to make a bigger effort in this final part because this is what other students and families will see. Incidentally, something very similar to the notetaking before writing took place during the production of the final product: two students did not make a final product in CBD. In that case, they took notes before writing and they also wrote a draft but, in the end, they did not deliver a final product to be corrected and displayed in the classroom whereas, within the PBLL approach, all the students finished their final product.

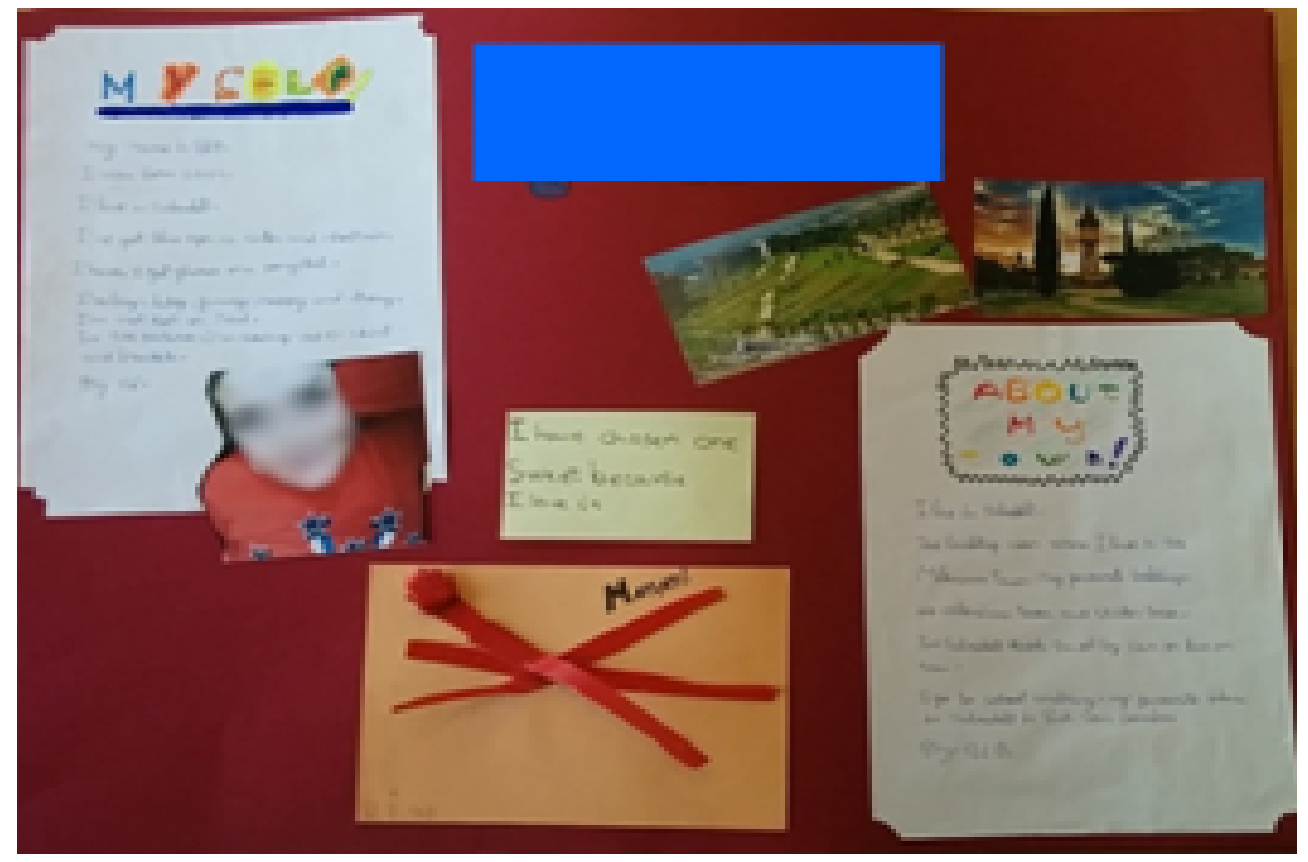

Fig. 5. Example of PBLL output

Moreover the final products done in the PBLL approach are much more creative than the ones produced in the CBD approach. They are more creative because the students were very engaged in innovating their posters by creating personal objects and sticking personal pictures, they used different materials, they took care of the visual arrangement and spatiality, they created multimodal productions, etc. as can be seen in the figure below. 


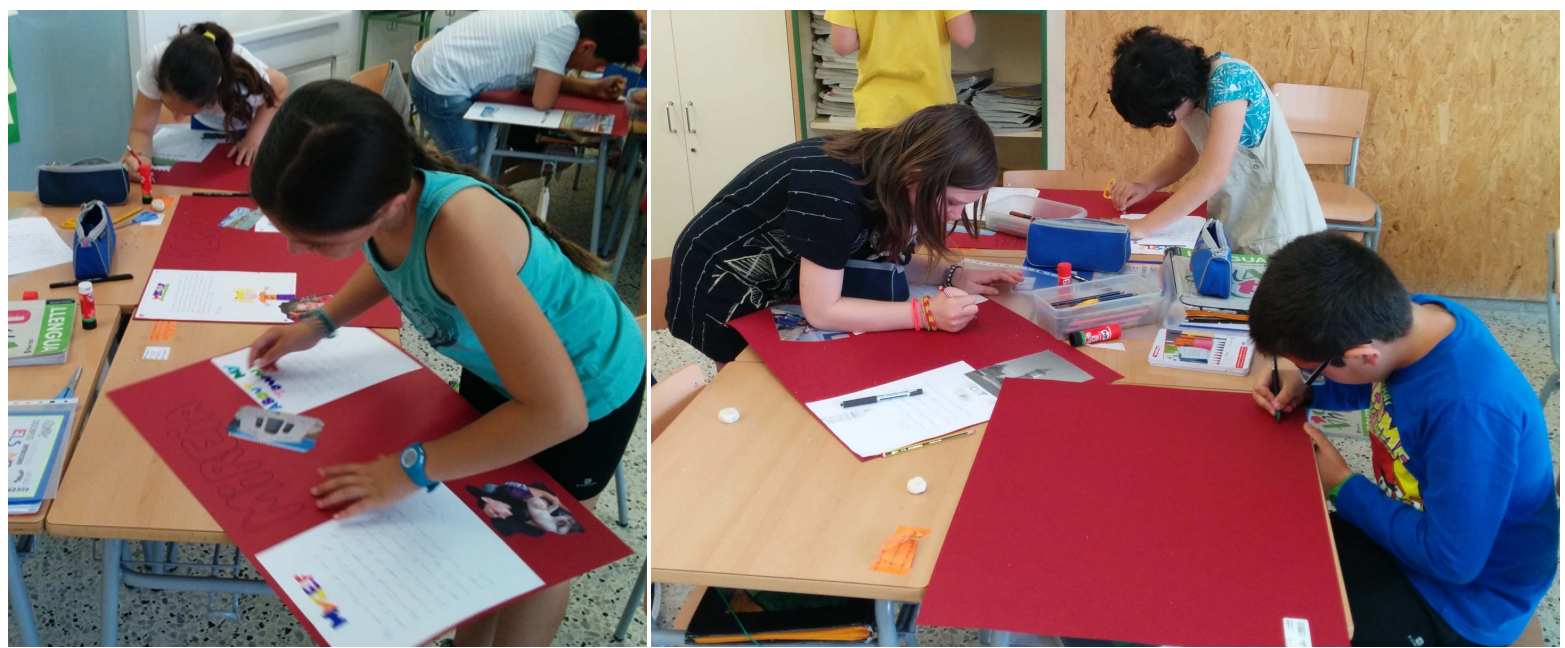

Fig. 6. Students complete their final output for PBLL approach

They even video $^{1}$ recorded themselves explaining things about their favourite object, clearly indicating student engagement in the project.

\section{Data set 2 analysis}

The information stemming from the focus group has been significant for the furthering of the research findings. In particular, the information gathered from the students' discussion has been very useful to answer the question "Are students more motivated when producing output in PBLL situation than in teacher-centred approach?" This will be discussed in further detail below.

As in the first data set, grounded theory was also applied in this phase, although in a slightly different way. Grounded theory refers to inductive theorizing that emerges from the corpus of data. It also implies taking a case-oriented perspective, with the assumption that variables of the dataset interact in complex ways (Charmaz, 2005). The basic idea of the grounded theory approach is to read (and re-read) a textual database (such as a corpus of field notes) and to observe the 'emergence' of frequently recurring features of the interaction and then to 'name' these variables (they may be called categories, concepts and properties), as well as noting their interrelationships, especially in terms of micro and macro thematic areas.

The first step in doing so is known as 'open coding', which is the part of the analysis concerned with identifying, naming, categorizing and describing phenomena found in the text.Thus, before analysing the extracts, a category analysis has been done. In this analysis there is a 'macro' thematic area, labelled motivation. In this thematic area, different categories can be found according to the information given by the four students who made up the focus group. The categories are 'safety', 'public display', 'foreign knowledge', 'other subjects 
involved', 'giving opinion', 'amount of writing', 'effort', 'innovation' and 'other'. In the first analysis, in which the macro-themes were drawn out, these categories occurred recurrently during the focus group discussion in different moments. They were mentioned by all the students separately. These topics were interpreted as being linked to the concept of 'motivation' (or being more engaged) and were called 'sub-topics'. The frequency of the subtopics that emerged from the data were then counted:

- Safety (9 comments)

- Public display (7 comments)

- Foreign knowledge (6 comments)

- Other subjects involved (6 comments)

- Giving opinion (4 comments)

- Amount of writing (4 comments)

- Effort (3 comments)

- Innovation (2 comments)

- Other (3 comments)

The following chart demonstrates the relationships between the categories and the comments produced by the students during the focus group. These categories and comments are discussed in more detail below.

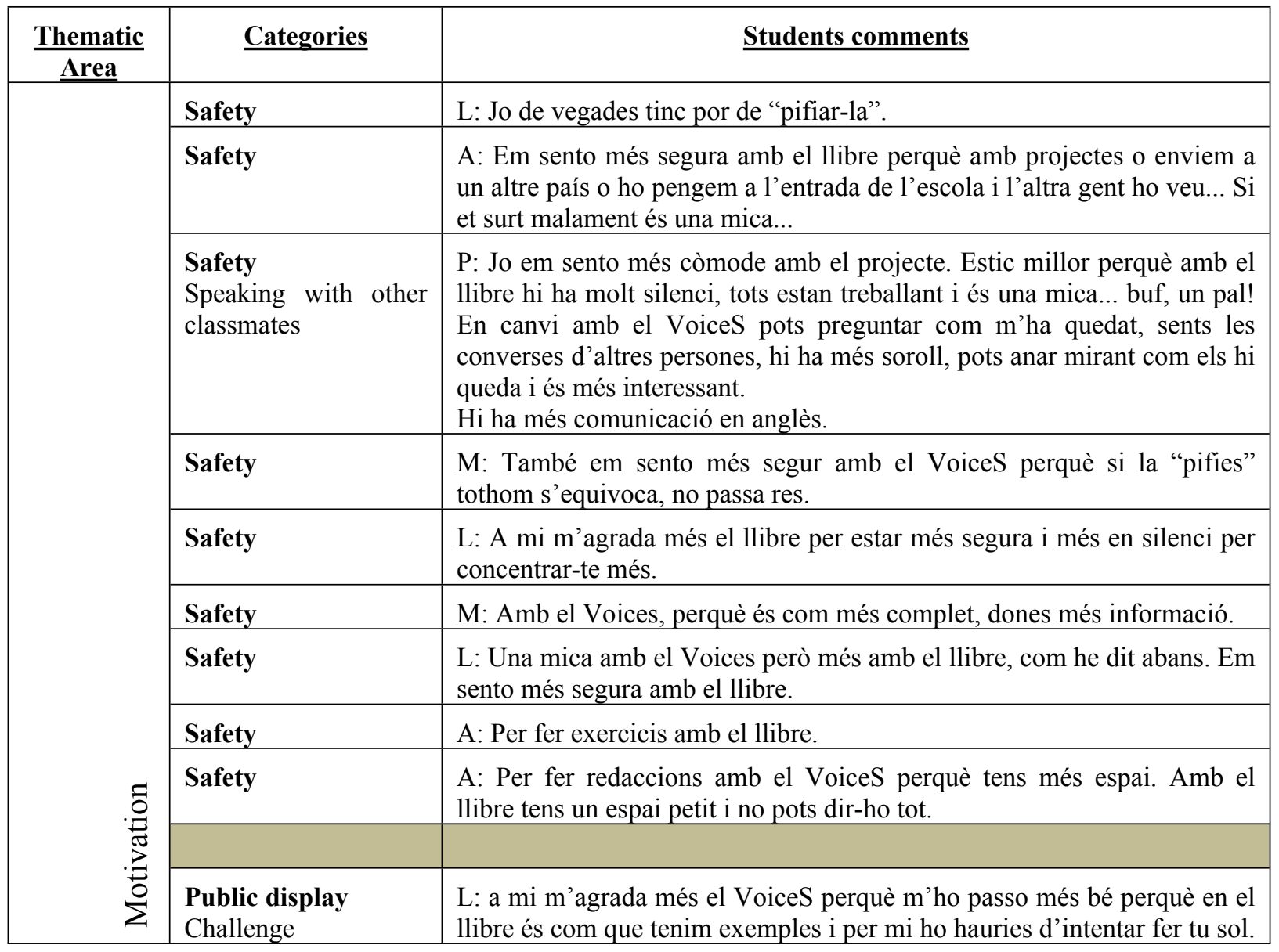




\begin{tabular}{|c|c|}
\hline & $\begin{array}{l}\text { I, com ha dit el M. que et fa una motivació de voler-ho fer molt bé } \\
\text { perquè tothom ho vegi que està bé. M'agrada més el VoiceS. }\end{array}$ \\
\hline $\begin{array}{l}\text { Public display } \\
\text { Amount of writing }\end{array}$ & $\begin{array}{l}\text { P: Escrius més coses perquè saps que aquesta cosa anirà a alumnes } \\
\text { estrangers i saps que lo del llibre es quedarà a la classe, només ho veu el } \\
\text { Javi i altres companys. Quan treballem per projectes també ho veuen } \\
\text { alumnes d'altres escoles i això fa que t'esforcis més. }\end{array}$ \\
\hline Public display & $\begin{array}{l}\text { A: Jo ho trobo molt bé, perquè tot el que nosaltres ens hem esforçat } \\
\text { llavors la gent ho veu i surt a compte. }\end{array}$ \\
\hline Public display & $\begin{array}{l}\text { P: És molt "guai" perquè així tothom sap que aquella feina l'hem fet } \\
\text { nosaltres. Surt a compte. }\end{array}$ \\
\hline Public display & $\begin{array}{l}\text { M: Encara que es trigui molt a fer (el projecte), quan ho acabes i et } \\
\text { queda molt bé. Lo del bloc em sembla molt bé perquè així les famílies } \\
\text { poden veure el que fem dins i forma de l'escola. }\end{array}$ \\
\hline $\begin{array}{l}\text { Public display } \\
\text { Foreign knowledge }\end{array}$ & $\begin{array}{l}\text { L: A mi m'agrada molt que s'exposin les coses i que s'enviïn a } \\
\text { l'estranger perquè així coneixen com som nosaltres, com és l'escola. } \\
\text { També m'agrada que ens enviïn coses per saber com són els altres. } \\
\text { M'agrada que s'exposi perquè així la gent veu el que fan els seus fills i } \\
\text { que ens hem esforçat molt durant tot l'any. }\end{array}$ \\
\hline Public display & $\begin{array}{l}\text { A: En el llibre no et diu que dibuixis. Igualment si t'ho diu, tu no } \\
\text { t'esforces tant perquè és com el llibre allà es queda, en secret. Si ho fas } \\
\text { en una cartolina en gran i ho envies a l'estranger o ho veuen els teus } \\
\text { pares és més xulu i veuen tot el que han fet. }\end{array}$ \\
\hline Foreign knowledge & $\begin{array}{l}\text { P: I també em motiva més perquè de vegades parlem amb d'altres } \\
\text { companys d'Europa i això és molt emocionant. }\end{array}$ \\
\hline Foreign knowledge & $\begin{array}{l}\text { M: És la millor part perquè així coneixes els costums dels altres països, } \\
\text { com són les seves escoles, si porten uniforme o no. I així podem } \\
\text { comparar amb la nostra i les altres. }\end{array}$ \\
\hline Foreign knowledge & $\begin{array}{l}\text { P: També podem saber si ens fan un vídeo, com ens van enviar els } \\
\text { d'Holanda, veus com són, quines diferències tenen, com parlen. També } \\
\text { és interessant saber com és la seva lletra. }\end{array}$ \\
\hline Foreign knowledge & $\begin{array}{l}\text { L: Va molt bé com diu el M. Va bé per saber com és l'escola, com la } \\
\text { tenen organitzada, si porten uniforme o no. }\end{array}$ \\
\hline $\begin{array}{l}\text { Foreign knowledge } \\
\text { Public display }\end{array}$ & $\begin{array}{l}\text { L: A mi m'agrada molt que s'exposin les coses i que s'enviïn a } \\
\text { l'estranger perquè així coneixen com som nosaltres, com és l'escola. } \\
\text { També m'agrada que ens enviïn coses per saber com són els altres. } \\
\text { M'agrada que s'exposi perquè així la gent veu el que fan els seus fills i } \\
\text { que ens hem esforçat molt durant tot l'any. }\end{array}$ \\
\hline $\begin{array}{l}\text { Foreign knowledge } \\
\text { Amount of writing } \\
\text { Speaking }\end{array}$ & $\begin{array}{l}\text { P: En el VoiceS es parla una mica més en anglès perquè escrius més, } \\
\text { veus més coses en anglès, t'ho corregeixen en anglès. Tot això va bé per } \\
\text { si vas a un país on es parla anglès t'anirà bé. }\end{array}$ \\
\hline $\begin{array}{l}\text { Other subjects } \\
\text { involved (ART) }\end{array}$ & $\begin{array}{l}\text { P: M'agrada més el VoiceS perquè és com el llibre però també està } \\
\text { barrejat amb l'art i la plàstica. }\end{array}$ \\
\hline $\begin{array}{l}\text { Other subjects } \\
\text { involved (ART) }\end{array}$ & $\begin{array}{l}\text { L: Era la cartolina, amb el "my self, el “,my favourite object”, el my } \\
\text { city" i el nom. }\end{array}$ \\
\hline $\begin{array}{l}\text { Other subjects } \\
\text { involved (ART) }\end{array}$ & M: Una fotografia del teu objecte preferit, de la teva ciutat... \\
\hline $\begin{array}{l}\text { Other subjects } \\
\text { involved (ART) }\end{array}$ & P: Amb el llibre és tot llapis i goma. \\
\hline Other subjects & L: Ens motiva molt fer el "myself", tots aquests. Fem servir llapis, \\
\hline
\end{tabular}




\begin{tabular}{|c|c|}
\hline involved (ART) & $\begin{array}{l}\text { retoladors, puntures, bolis, dibuixos d'art fets amb la Laura (mestra } \\
\text { d'art). }\end{array}$ \\
\hline $\begin{array}{l}\text { Other subjects } \\
\text { involved (ART) }\end{array}$ & $\begin{array}{l}\text { A: En el llibre no et diu que dibuixis. Igualment si t'ho diu, tu no } \\
\text { t'esforces tant perquè és com el llibre allà es queda, en secret. Si ho fas } \\
\text { en una cartolina en gran i ho envies a l'estranger o ho veuen els teus } \\
\text { pares és més xulu i veuen tot el que han fet. }\end{array}$ \\
\hline Giving opinion & $\begin{array}{l}\text { M: En els projectes li donem molta més motivació que en els llibres, } \\
\text { perquè en els llibres és com més avorrit. En canvi en el VoiceS, pots } \\
\text { donar la teva opinió. }\end{array}$ \\
\hline $\begin{array}{l}\text { Giving opinion } \\
\text { Amount of writing }\end{array}$ & $\begin{array}{l}\text { M: En VoiceS es veu a simple vista que és molt més llarg i pots donar la } \\
\text { teva opinió. En canvi al llibre no et deixen espai per fer-ho. }\end{array}$ \\
\hline Giving opinion & $\begin{array}{l}\text { M: Al VoiceS has de donar més la teva opinió, en canvi al llibre és més } \\
\text { "dale que te pego". També per donar la teva opinió has d'utilitzar } \\
\text { paraules més complexes. }\end{array}$ \\
\hline Giving opinion & $\begin{array}{l}\text { L: És més complex perquè s'entén més, dones més la teva opinió, queda } \\
\text { més bonic que al llibre. }\end{array}$ \\
\hline $\begin{array}{l}\text { Amount of writing } \\
\text { Public display }\end{array}$ & $\begin{array}{l}\text { P: Escrius més coses perquè saps que aquesta cosa anirà a alumnes } \\
\text { estrangers i saps que lo del llibre es quedarà a la classe, només ho veu el } \\
\text { Javi i altres companys. Quan treballem per projectes també ho veuen } \\
\text { alumnes d'altres escoles i això fa que t'esforcis més. }\end{array}$ \\
\hline $\begin{array}{l}\text { Amount of writing } \\
\text { Foreign knowledge } \\
\text { Speaking }\end{array}$ & $\begin{array}{l}\text { P: En el VoiceS es parla una mica més en anglès perquè escrius més, } \\
\text { veus més coses en anglès, t'ho corregeixen en anglès. Tot això va bé per } \\
\text { si vas a un país on es parla anglès t'anirà bé. }\end{array}$ \\
\hline $\begin{array}{l}\text { Amount of writing } \\
\text { Giving opinion }\end{array}$ & $\begin{array}{l}\text { M: En VoiceS es veu a simple vista que és molt més llarg i pots donar la } \\
\text { teva opinió. En canvi al llibre no et deixen espai per fer-ho. }\end{array}$ \\
\hline Amount of writing & $\begin{array}{l}\text { P: En el projecte es veu clarament que és tot un text i hi ha molta lletra. } \\
\text { En canvi en el llibre són frases i no és tanta lletra. }\end{array}$ \\
\hline Effort & $\begin{array}{l}\text { A: A mi m'agrada més els projectes perquè així no tens un exemple a } \\
\text { seguir, pots escriure el que tu vulguis però que vagi del tema i és més } \\
\text { divertit i t'hi esforces més. }\end{array}$ \\
\hline $\begin{array}{l}\text { Effort } \\
\text { Innovation }\end{array}$ & $\begin{array}{l}\text { A: Trobo que la gent ho troba més interessant i no s'hi esforça tant en el } \\
\text { llibre perquè gairebé sempre fem el mateix i llavors quan fem un } \\
\text { projecte canviem i a tothom "se li surten les coses". }\end{array}$ \\
\hline $\begin{array}{l}\text { Effort } \\
\text { Better writing }\end{array}$ & $\begin{array}{l}\text { L: Com ha dit el M. En el VoiceS ens esforcem més, fem millor lletra. } \\
\text { En el llibre no et pots expressar tant bé. }\end{array}$ \\
\hline Innovation & $\begin{array}{l}\text { A: A mi m'agrada més els projectes perquè així no tens un exemple a } \\
\text { seguir, pots escriure el que tu vulguis però que vagi del tema i és més } \\
\text { divertit i t'hi esforces més. }\end{array}$ \\
\hline $\begin{array}{l}\text { Innovation } \\
\text { Effort }\end{array}$ & $\begin{array}{l}\text { A: Trobo que la gent ho troba més interessant i no s'hi esforça tant en el } \\
\text { llibre perquè gairebé sempre fem el mateix i llavors quan fem un } \\
\text { projecte canviem i a tothom "se li surten les coses". }\end{array}$ \\
\hline Other & L: M'agrada més el VoiceS per poder parlar, com ha dit el P. \\
\hline & $\begin{array}{l}\text { P: Com diu el M. així veus el resultat, fas tot. Fas tots els escrits i tot i } \\
\text { després ho enganxes a la cartolina. Veus lo bé que t'ha quedat. }\end{array}$ \\
\hline & M: És més divertit fer-ho amb el "myself". Treballem amb grup i amb el \\
\hline
\end{tabular}




\begin{tabular}{|l|l|l|}
\hline & $\begin{array}{l}\text { llibre és tot llapis i boli verd (correccions). Jo com m'equivoco, tinc el } \\
\text { llibre verd. }\end{array}$ \\
\hline
\end{tabular}

Table 2. Relationship between categories and comments from the focus group discussion

The next step consisted of what is known as 'saturation' (Bryant \& Charmaz, 2007). This consists of ensuring that all concepts that have emerged can be substantiated from the data. In this case, this has been done through qualitative content analysis of the focus group discussion (Mayring, 2000). This offers the opportunity to compare and complement the categories with sources from the primary data (Kohlbacher, 2005). For the sake of brevity only one detailed analysis is discussed here, however, in the full study each category is deglossed in the same manner. The example given here deals with the category 'safey' which was the most salient for the focus group participants (as determined by holding the highest frequency). The discussion took place in Catalan, to facilitate the participation of the young language learners. The fragment in its original version can be viewed in the annex.

Fragment 1: 'safety'. Participants: I (investigator), A (student A), L (student L), M (student $\mathrm{M})$ and $\mathrm{P}$ (student $\mathrm{P}$ ).

11. P: We also know if we do a video like the one we were sent from Holland, we can see how they are, what differences they have, how they speak. It is also interesting to know how they write [script].

12. L: Like M says, it's good. It's good to know how the school is organized, if wear uniform or not. Sometimes I'm afraid of 'flubbing it.'

13. I: If we are wrong, it's not a problem.

14. I: They say that when we follow the examples the book gives us we are following a model. When do you feel more 'secure' and more relaxed when you are working? When you are working with the book or on the project? Or does one thing have an impact on the other and vice-versa?

15. A: I feel safer with the book because with the projects or it gets sent to another country or else they hang it at the entrance of the school and other people see it ... If you get something wrong it's ...

16. P: I feel more comfortable with the project. I feel better because with the book there is so much silence, and everyone is working ... uff! Boring! In contrast with the VoiceS [EU Project] you can ask how it's going, hear the conversations of other people, there is more noise, you can walk around and see how other people's work is going and it is more interesting.

17. I: Maybe there is more communication in English?

18. P: Yes. 
19. M: Like P said, I also feel more comfortable with VoiceS because if you 'flub it' it doesn't matter.

20. L: I also feel more secure, like A. Because, I don't know, with VoiceS I don't want to 'flub it up' because I do care what others think. I like the book more in order to feel safer and it's quieter to concentrate more. I like the VoiceS project for speaking, like P said.

21. I: So, if we have to write a text explaining something how you think it would be better? How would you feel safer?

22. M: With VoiceS, because it is more complete, you give more information.

23. L: A bit with Voices but more with the book, as I said earlier. I feel safer with the book.

24. P: Like M says. That way [working with the project] you see the results, you do everything. You do all the texts and everything and then paste it on a poster. You get to see how good it turned out.

25. A: Safer with Voices. But to do exercise activities, best with the book. To write texts, best with Voices, you have more space. With the book you have just a little space and you can't say everything.

26. I: When we do project work, everything is a little more free, right? In general what differences do you see with the texts we have done in relation to the book and related to the project? This is what I've really been analyzing a lot.

As it can be seen in this short fragment, the feelings about which approach to language teaching makes them feel more confident is evenly divided. On the one hand, two of the students feel safer (more secure, more confident) when they work following a CBD methodology because they are afraid of making mistakes when their output is shown to the rest of the school or sent to foreign students. In turn 23, student L says "I feel safer with the book". She had already indicated that sometimes she was afraid of making mistakes (turn 12): Sometimes I'm afraid of 'flubbing it'. She agrees with student A when she says, "I also feel more secure, like A. Because, I don't know, with VoiceS [EU project] I don't want to 'flub it up' because I do care what others think". Also in turn 20, student L says she feels safer in a quiet atmosphere because she can concentrate better.

In turn 15, student A feels safer when her productions are not publicly displayed: "I feel safer with the book because with the projects or it gets sent to another country or else they hang it at the entrance of the school and other people see it ... If you get something wrong it's ...". In turn 25, this same student reiterates that she feels more confident and secure with the book to do language exercices.

On the other hand, it can also be observed that there are two students who feel safer when they work following a PBLL methodology. Student P, in turn 16, says he feels more 
comfortable with the project approach and that he prefers noisy classes because he can talk to his mates and ask for opinions and he adds that silence is tedious: "I feel better because with the book there is so much silence, and everyone is working ... uff! Boring!" He also says there is more communication in English (turn 18). Student $M$ is not worried about making mistakes, because everybody makes them and "it doesn't matter" (turn 19). This follows the line of thought previously put forth by the teacher-investigator that making mistakes is not a problem (turn 13). Student M alsosays that with PBLL they give more information turn 22). Finally, in turn 25, student A says that she feels safer writing compositions when doing projects because they have more space. She adds that with the book you have a little space and they cannot write everything they might want. "With the book you have just a little space and you can't say everything".

\section{Conclusion}

This research has tried to answer different questions. The first question that the teacherresearcher has asked himself is "Do PBLL and CBD approaches result in different language learning?" After analysing the data coming from the students' productions, there is clear evidence of differences between the writings following a CBD approach and the writings following a PBLL approach. The answer, then for this first question is yes. The PBLL approach resulted in texts that had more complexity in syntax, lexicon as well as showing more creative effort to communicate to an 'authentic' audience.

The second question is "Can PBLL be applied to writing in contexts which are predominantly oral-production focused?" again the answer is yes. This second question was then refined with these two extra questions -Is there evidence of gains in (written) language use in PBLL-derived output in comparison to the other approach? and -Are students more motivated when producing output in PBLL situation than in teacher-centred approach (CBD)? Once more, all the questions are answered with a yes. Even if the oral production is an important part in the teaching-learning process of any language, writing is also an important aspect. And, according to this paper and to the data analysis, PBLL can be applied to writing, even when the classroom procedures highlight oral production more frequently.

In summary, after analysing "data set 1", there is evidence of more gains in the target written language when the PBLL approach is used. For example, students write longer texts, use more adjectives, create complex and compound sentences, use the passive voice, justify why they like something using the connector "because", etc. In addition, when analysing the 
focus group (data set 2), students say that they are more motivated when working in a project because there is real audience and their final productions are seen by a lot of people, they know information about foreign students, they can give their opinions, etc. There is a general consensus on this, despite the voiced concerns that having this 'real' audience does increase the amount of anxiety they feel about their own output. This implies that the teacher must carefully scaffold the PBLL approach to ensure that the learners feel the same security they would if working in a possibly more familiar environment of producing output only for the teacher as the main recipient of their work.

There are, inevitably, limitations to this study. Firstly, the study derives from a qualitative research framed in a year-long master course. It is the analysis of data that belongs to four 10/11-year-old students from a specific school in Sabadell. In action-research, the relationship between the researcher (also teacher) and the students is friendlier and less formal than in a quantitative research, where the investigator, perhaps, does not know the participants. In addition, the researcher has only focused in the analysis of the data of the four students previously mentioned. Therefore, the results of this research cannot be generalized. Future studies should include more longitudinal data and analysis and could be extended to include students from different schools. Perhaps researchers around the country could do the same investigation in order to generalize the results.

Nonetheless, it can be concluded that the results are heartening for anyone interested in using a PBLL methodology. It has proven to be a very interesting tool to learn languages in a meaningful way for the students and there are significant learning gains, including carryover from oral output to written production in the target language.

\section{References}

Adelman, C. (1993). Kurt Lewin and the origins of action research. Educational Action Research, 1(1): 7-24. https://doi.org/10.1080/0965079930010102

Allwright, D. (2003). Exploratory Practice: rethinking practitioner research in language teaching. Language Teaching Research, April 7, 113-141. https://doi.org/10.1191/13621688031r118oa

Bartlett, S., \& Burton, D. (2006). Practitioner research or descriptions of classroom practice? A discussion of teachers investigating their classrooms. Educational Action Research, 14(3): 395-405. https://doi.org/10.1080/09650790600847735

Beckett, G.H., \& Miller, P.C. (2006). Project-based second and foreign language education: Past, present, and future. Charlotte, NC: Information Age Publishing.

Bryant A., \& Charmaz, K. (Eds.) (2007). Handbook of grounded theory. London: Sage.

Chapman, C., Ramondt, L., \& Smiley, G. (2005). Strong community, deep learning: Exploring the link. Innovations in Education and Teaching International, 42(3), 217230. https://doi.org/10.1080/01587910500167910 
Charmaz, K. (2006). Constructing grounded theory: A practical guide through qualitative analysis. London: Sage.

Dooly, M. (2010). Their hopes and fears: A catalyst for project-based language learning. In M. Dooly (Ed.) Their hopes, fears and reality: Working with children and youth for the future (pp. 99-132). Bern: Peter Lang.

Dooly, M. (2013). Promoting competency-based language teaching through project-based language learning. In M.L. Pérez-Cañado (Ed.) Competency-based language teaching in higher education (pp. 77-92). Dordrecht: Springer.

Dooly, M. (2016). Proyectos didácticos para aprender lenguas. In D. Masats \& L. Nussbaum (Eds.) Enseñanza y aprendizaje de las lenguas extranjeras en educación secundaria obligatoria (pp.169-193). Madrid: Síntesis.

Ferrance, E. (2000). Action research. Providence, RI: Northeast and Islands Regional Educational Laboratory at Brown University. Available at https://www.brown.edu/academics/educationalliance/sites/brown.edu.academics.educationalliance/files/publications/act_research.pdf

Glaser, B. G. (1978). Theoretical sensitivity. Mill Valley, CA: Sociology Press.

Goodrich, H., Hatch, T., Wiatrowski, G., \& Unger, C. (1995). Teaching through projects: Creating effective learning environments. CA: Innovative Learning Publications.

Kara, H. (2012). Research and evaluation for busy practitioners: a time-saving guide, p.1. Bristol: The Policy Press.

Kara, H. (2012). Research and evaluation for busy practitioners: a time-saving guide. Bristol: The Policy Press.

Kohlbacher, F. (2005). The Use of Qualitative Content Analysis in Case Study Research [89 paragraphs]. Forum Qualitative Sozialforschung / Forum: Qualitative Social Research, 7(1), Art. 21, http://nbn-resolving.de/urn:nbn:de:0114-fqs0601211.

Krueger, R. (1991). El grupo de discusión. Guía práctica de la investigación aplicada. Madrid: Pirámide.

Lantolf, J.P. (2000). Sociocultural theory of language learning. Oxford: Oxford University Press.

Lantolf, J.P. (2004). Overview of sociocultural theory. In O. St. John, K. van Esch \& E. Schalkwijk (Eds.). New insights in second language learning and teaching (pp. 1334). Frankfurt: Peter Lang Verlag.

Lantolf, J.P., \& Poehner, M.E. (2008). Sociocultural theory and the teaching of second languages. London: Equinox.

Masats, D., Nussbaum, L., \& Unamuno, V. (2007). When activity shapes the repertoire of second language learners. In L. Roberts, A. Gurel, S. Tatar \& L. Martí (Eds.), EUROSLA Yearbook: Volume 7 (pp. 121-147). Amsterdam: John Benjamins Publishing Company.

Mayring, P. (2000, June). Qualitative content analysis [28 paragraphs]. Forum Qualitative Sozialforschung / Forum: Qualitative Social Research [On-line Journal], 1(2), Art. 20. Available at: http://www.qualitative-research.net/fqs-texte/2-00/2-00mayring-e.htm.

Negueruela-Azarola, E., García, P., \& Buescher, K. (2015). From interaction to intra-action: The internalization of talk, gesture, and concepts in the second language classroom. In N. Markee (Ed.) The handbook of classroom discourse and interaction (pp. 233-248). Malden, MA: John Wiley \& Sons.

Pine, G. J. (2009). Teacher action research: Building knowledge democracies. Los Angeles: Sage. 
Sagor, R. (2000). Guiding school improvement with action research. Alexandria, VA: Association for Supervision and Curriculum Development (ASCD). Available at http://www.ascd.org/publications/books/100047.aspx

Sierra, J.M. (2011). CLIL and project work: Contributions from the classroom. In Y. Ruiz de Zarobe, J.M. Sierra, \& F. Gallardo del Puerto (Eds.) Content and foreign language integrated learning (pp. 211-240). Bern: Peter Lang.

Stoller, F. (2002). Project work: A means to promote language and content. In J.C. Richards \& A.R. Willy (Eds.), Methodology in language teaching: An anthology of current practice (pp. 107-120). Cambridge: Cambridge University Press.

Strauss, A., \& Corbin, J. (1990). Basics of qualitative research: Grounded theory procedures and techniques. Newbury Park, CA: Sage.

Stringer, E. T. (2007). Action research in education. Upper Saddle River, N.J: Prentice Hall.

Van Lier, L. (2000). From input to affordance: Social-interactive learning from an ecological perspective. In J. Lantolf (ed), Sociocultural theory and second language learning (pp. 245-259). Oxford: Oxford University Press.

Vygotsky, L. S. (1978). Mind in society: The development of higher psychological processes. Cambridge, MA: Harvard University Press.

Wenger, E. (2015). Communities of practice: a brief introduction. Retrieved 12 March 2015 from: http://wenger-trayner.com/wp-content/uploads/2015/04/07-Brief-introductionto-communities-of-practice.pdf

\footnotetext{
${ }^{1}$ These recordings can be viewed at:

http://somelsdecinquedenostrallar.blogspot.com.es/2014/10/expressart.html
}

\section{Acknowledgements}

This article is derived from my Master's dissertation directed by Dr. Melinda Dooly at the Universitat Autònoma de Barcelona and with the support of the research centre GREIP.

\section{Annex}

11. P: També podem saber si ens fan un vídeo, com ens van enviar els d'Holanda, veus com són, quines diferències tenen, com parlen. També és interessant saber com és la seva lletra.

12. L: Va molt bé com diu el M. Va bé per saber com és l'escola, com la tenen organitzada, si porten uniforme o no. Jo de vegades tinc por de 'pifiar-la'.

13. I: Si ens equivoquem, tampoc passa res.

14. I: Dieu que quan seguim el llibre seguim exemples, ens dóna un model. Com us sentiu més segurs i més tranquils a l'hora de treballar? Quan treballem amb el llibre o quan és projecte (aquí una cosa tira cap a una banda i l'altre cap a una altra banda?

15. A: Em sento més segura amb el llibre perquè amb projectes o enviem a un altre país o ho pengem a l'entrada de l'escola i l'altra gent ho veu... Si et surt malament és una mica...

16. P: Jo em sento més còmode amb el projecte. Estic millor perquè amb el llibre hi ha molt silenci, tots estan treballant i és una mica... buf, un pal! En canvi amb el VoiceS [EU project] pots preguntar com m'ha queda, sents les converses d'altres persones, hi ha més soroll, pots anar mirant com els hi queda i és més interessant. 
17. I: Potser hi ha més comunicació en anglès?

18. P: Sí.

19. M: Com ha dit el P., també em sento més segur amb el Voices perquè si la 'pifies' tothom s'equivoca, no passa res.

20. L: Jo em sento més segura, igual que 1'A., perquè no sé, amb el Voices no la vull 'pifiar' perquè a mi sí m'importa el que pensin els altres. A mi m'agrada més el llibre per estar més segura i més en silenci per concentrar-te més. M'agrada més el VoiceS per poder parlar, com ha dit el P.

21. I: Per tant, si em de fer un escrit explicant qualsevol cosa de quina manera penseu que sortirà millor? Com us sentiu més segurs?

22. M: Amb el Voices, perquè és com més complet, dones més informació.

23. L: Una mica amb el Voices però més amb el llibre, com he dit abans. Em sento més segura amb el llibre.

24. P: Com diu el M. Així veus el resultat, fas tot. Fas tots els escrits i tot i després ho enganxes a la cartolina. Veus lo bé que t'ha quedat.

25. A: Més segura amb el Voices. Per fer exercicis i tot amb el llibre. Per fer redaccions amb el Voices perquè tens més espai. Amb el llibre tens un espai petit i no pots dir-ho tot.

26. I: Quan treballem per projectes, tot és una mica més lliure, no? Quines diferències veieu a simple vista entre els escrits que hem fet relacionant-los amb el llibre i aquests escrits relacionats amb el projecte? Jo això ho he estat analitzant molt.

(return to text)

Javier Barba is an associate professor in the Department of Language, Literature and Social Sciences Education at the Universitat Autònoma de Barcelona. He has many years of experience as a primary education teacher and has participated in several European projects. He recently completed his Masters degree in Education Research at the Universitat Autònoma de Barcelona.

Email: javier.barba@uab.cat

To cite this article:

Barba, J. (2016). EXPRESSART: A Project-Based Language Learning Experience. Bellaterra Journal of Teaching \& Learning Language \& Literature, 9(4), 59-81. http://dx.doi.org/10.5565/rev/itl3.689

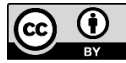

